\title{
Heteromeric Nicotinic Acetylcholine-Dopamine Autoreceptor Complexes Modulate Striatal Dopamine Release
}

\author{
Davide Quarta', Francisco Ciruela ${ }^{2}$, Kshitij Patkar', Janusz Borycz', Marcello Solinas', Carme Lluis², \\ Rafael Franco', Roy A Wise', Steven R Goldberg', Bruce T Hope', Amina S Woods ${ }^{3}$ and Sergi Ferré*,' \\ 'Behavioral Neuroscience Branch, National Institute on Drug Abuse, IRP, NIH, DHHS, Baltimore, MD, USA; ${ }^{2}$ Department of Biochemistry and \\ Molecular Biology, University of Barcelona, Barcelona, Spain; ${ }^{3}$ Cellular Neurobiology Branch, National Institute on Drug Abuse, IRP, NIH, DHHS, \\ Baltimore, MD, USA
}

\begin{abstract}
In the striatum, dopamine and acetylcholine (ACh) modulate dopamine release by acting, respectively, on dopamine $D_{2}$ autoreceptors and nicotinic $\mathrm{ACh}(\mathrm{nACh}$ ) heteroreceptors localized on dopaminergic nerve terminals. The possibility that functional interactions exist between striatal $D_{2}$ autoreceptors and $n A C h$ receptors was studied with in vivo microdialysis in freely moving rats. Local perfusion of nicotine in the ventral striatum (shell of the nucleus accumbens) produced a marked increase in the extracellular levels of dopamine, which was completely counteracted by co-perfusion with either the non- $\alpha_{7} \mathrm{nACh}$ receptor antagonist dihydro- $\beta$-erythroidine or the $D_{2-3}$ receptor agonist quinpirole. Local perfusion of the $D_{2-3}$ receptor antagonist raclopride produced an increase in the extracellular levels of dopamine, which was partially, but significantly, counteracted by coperfusion with dihydro- $\beta$-erythroidine. These findings demonstrate a potent crosstalk between $G$ protein-coupled receptors and ligand-gated ion channels in dopaminergic nerve terminals, with the $D_{2}$ autoreceptor modulating the efficacy of non- $\alpha_{7} n A C h$ receptor-mediated modulation of dopamine release. We further demonstrate physical interactions between $\beta_{2}$ subunits of non- $\alpha_{7}$ nicotinic acetylcholine receptors and $D_{2}$ autoreceptors in coimmunoprecipitation experiments with membrane preparations from co-transfected mammalian cells and rat striatum. These results reveal that striatal non- $\alpha_{7}$ nicotinic acetylcholine receptors form part of heteromeric dopamine autoreceptor complexes that modulate dopamine release.

Neuropsychopharmacology (2007) 32, 35-42. doi: I0.1038/sj.npp. I 30 I 103; published online 17 May 2006
\end{abstract}

Keywords: dopamine $\mathrm{D}_{2}$ receptor; nicotinic acetylcholine receptor; autoreceptor; heteroreceptor; dopamine release; striatum

\section{INTRODUCTION}

In the central nervous system (CNS), ligand-gated ion channels can be found presynaptically, in nerve terminals, where they control neurotransmitter release (Engelman and MacDermott, 2004). Among them, nicotinic acetylcholine (nACh) receptors constitute a particular example, as nACh receptor-mediated modulation (stimulation) of neurotransmitter release is more pronounced than the relatively low numbers of neuronal nACh receptors might predict, suggesting that this is a main function of $\mathrm{nACh}$ receptors in the brain (Wonnacott, 1997). Thus, nACh receptors play

\footnotetext{
*Correspondence: Dr S Ferré, Behavioral Neuroscience Branch, National Institute on Drug Abuse, IRP, NIH, DHHS, 5500 Nathan Shock Dr., Baltimore, MD 21224, USA, Tel: + I 410550 1586, Fax: + | 410550 1648, E-mail: sferre@intra.nida.nih.gov

Received 27 December 2005; revised 24 March 2006; accepted 4 April 2006

Online publication: 18 April 2006 at http://www.acnp.org/citations/ Npp04/806050773/default.pdf
}

mostly a modulatory role in the CNS, in contrast to neuromuscular junctions and autonomic ganglia, where nACh receptors mediate postsynaptic, fast, excitatory neurotransmission (Wonnacott, 1997; Vizi and Lendvai, 1999).

Neuronal nACh receptors are heteromeric pentamers made of a heterogeneous family of eight different subunits $\left(\alpha_{3-7}, \beta_{2-4}\right)$. Neuronal nACh receptors can be subdivided into $\alpha$-bungarotoxin-sensitive or homomeric $\alpha_{7} \mathrm{nACh}$ receptors and $\alpha$-bungarotoxin-insensitive or heteromeric non- $\alpha_{7}$ nACh receptors. In the striatum, most nACh receptors are heteromeric, containing $\alpha$ and $\beta$ subunits. Almost all of these heteromeric receptors contain the $\beta_{2}$ subunit, whereas $\alpha_{4}$ and $\alpha_{6}$ are the most represented $\alpha$ subunits (Zoli et al, 2002). Dopaminergic terminals seem to be the predominant localization of striatal $\mathrm{nACh}$ receptors (Wonnacott et al, 2000; Jones et al, 2001; Zoli et al, 2002) and results obtained from numerous experiments performed both in vitro (striatal synaptosomes or slices) and in vivo (microdialysis) have demonstrated that stimulation of 
these presynaptic nACh receptors results in dopamine (DA) release (Mifsud et al, 1989; Nakamura et al, 1992; Toth et al, 1992; Nisell et al, 1994; Sacaan et al, 1995; Clarke and Reuben, 1996; Marshall et al, 1997; Wonnacott et al, 2000; Kulak et al, 2001; Zhou et al, 2001; Ferrari et al, 2002; Grady et al, 2002; Champtiaux et al, 2003).

G-protein-coupled receptors (GPCRs) can also be found in presynaptic nerve terminals. Dopaminergic nerve terminals possess DA $\mathrm{D}_{2}$ autoreceptors, which, when stimulated, inhibit dopaminergic neurotransmission. Multiple mechanisms have been suggested to be involved in the $D_{2}$ autoreceptor-mediated modulation of DA release. These include the reduction of membrane excitability by increasing a $\mathrm{K}^{+}$conductance (Cass and Zahniser, 1991; Congar et al, 2002), the decrease of DA synthesis and packaging (Onali et al, 1988; Pothos et al, 1998) and the upregulation of the DA transporter (Gulley and Zahniser, 2003). The present study demonstrates a new and important functional mechanism that allows $\mathrm{D}_{2}$ autoreceptors to decrease dopaminergic neurotransmission, based on the existence of functional and physical interactions between $\mathrm{D}_{2}$ autoreceptors and non- $\alpha_{7} \mathrm{nACh}$ receptors in the striatum.

\section{MATERIALS AND METHODS}

\section{Subjects and Drugs}

Male Sprague-Dawley rats, weighing 300-350 g, were used in all experiments. Animals were maintained in accordance with guidelines of the Institutional Care and Use Committee of the Intramural Research Program, National Institute on Drug Abuse, NIH. (-)-Nicotine hydrogen tartrate salt ([-]-1-methyl-2-[3-pyridyl] pyrrolidine), quinpirole hydrochloride, and raclopride tartrate were purchased from Sigma Chemical Co. (St Louis, MO); dihydro- $\beta$-erythroidine hydrobromide $(\mathrm{DH} \beta \mathrm{E})$ was purchased from RBI (Research Biochemicals International, Natick, MA). Cocaine $\mathrm{HCl}$ was obtained from the National Institute on Drug Abuse (NIDA Pharmacy, Baltimore, MD).

\section{In Vivo Microdialysis}

Concentric microdialysis probes were prepared as described previously (Pontieri et al, 1995). Animals were anesthetized with a solution of $4.44 \%$ chloral hydrate and $0.97 \% \mathrm{Na}$ pentobarbital (NIDA Pharmacy, Baltimore, MD) and probes were implanted in the shell of the NAc (coordinates with respect to bregma: anterior, +2.2; lateral, -1.0 ; ventral, 7.7 from the dura). Experiments were performed on freely moving rats $24 \mathrm{~h}$ after probe implantation. All drugs were freshly dissolved in a Ringer solution $(147 \mathrm{mM} \mathrm{NaCl}, 4 \mathrm{mM}$ $\mathrm{KCl}$, and $2.2 \mathrm{mM} \mathrm{CaCl} 2$ ) and $\mathrm{pH}$ was corrected when necessary. Ringer solution, either pure (during drug preperfusion and wash-out periods) or containing different concentrations of DA and $\mathrm{nACh}$ receptor agonists or antagonists alone or in combination (drug perfusion period), was pumped through the dialysis probe at a constant rate of $1 \mu \mathrm{l} / \mathrm{min}$ and samples were collected at 20 min intervals. Each animal was used to study the effect of one treatment by local administration (perfusion by reverse dialysis). At the end of the experiment, rats were killed with an overdose of Equithesin and methylene blue was perfused through the probe. The brain was removed and placed in a $10 \%$ formaldehyde solution, and coronal sections were cut to verify probe location. Dialysate DA content was measured by reverse high-performance liquid chromatography coupled to an electrochemical detector, as described in detail previously (Pontieri et al, 1995). The statistical analysis used was the 'summary measures' method (Matthews et al, 1990), using the mean of the three values previous to drug administration (basal value) and the mean of the three values during drug perfusion (perfusion value) per animal as the summary measures. Repeated measures analysis variance (ANOVA) (one-way and two-way) with Bonferroni post hoc comparisons were used to analyze differences within (basal $v s$ perfusion) and between treatments (GraphPad-Prism version 4 software, San Diego, CA). The $p$-values shown in the figures refer to differences between basal $v s$ perfusion values for each treatment.

\section{Plasmid Constructs}

The myc epitope (EQKLISEEDL) was introduced between $\mathrm{Thr}_{32}$ and $\mathrm{Arg}_{33}$, after the signal peptide $\left(\mathrm{Met}_{1}-\mathrm{Ser}_{27}\right)$, of the human $\alpha_{4}$ subunit of the nACh receptor (kindly provided by JM Lindstrom, Department of Neuroscience, University of Pennsylvania Medical School, Philadelphia, PA) using a PCR mutagenesis approach (Ferré et al, 2002) and cloned into the HindIII/EcoRI sites of pcDNA3.1 (Invitrogen, Carlsbad, CA, USA). The cDNA encoding the human $\beta_{2}$ subunit of the nACh receptor (also provided by JM Lindstrom) was cloned into the EcoRI site of pcDNA3.1. The human $D_{2 S}$ receptor containing a hemaglutinin (HA) epitope (YPYDVPDYALV) between $\mathrm{Asp}_{2}$ and $\mathrm{Pro}_{3}$ (kindly provided by SL Milgram, Department of Cell and Molecular Physiology and the Curriculum in Neurobiology, The University of North Carolina at Chapel Hill, Chapel Hill, NC) was cloned into HindIII/XbaI sites of pcDNA3.1. The sequences of the cDNAs and their orientation in the vectors were confirmed by DNA sequencing.

\section{Antibodies}

The primary antibodies were: goat anti- $\alpha_{4} \mathrm{nACh}$ receptor polyclonal antibody (A-20; Santa Cruz Biotechnology Inc., Santa Cruz, CA), rabbit anti- $\beta_{2}$ nACh receptor polyclonal antibody (H-92; Santa Cruz Biotechnology), rat anti- $\beta_{2}$ $\mathrm{nACh}$ receptor monoclonal antibody (Clone mAb270; Sigma), rabbit anti- $\mathrm{D}_{2}$ receptor polyclonal antibody $\left(\mathrm{D}_{2}-\right.$ 246-316; previously; Bjelke et al, 1996), mouse anti-cmyc monoclonal antibody (Clone 9E10; Sigma), mouse anti-HA monoclonal antibody (Clone 12CA5; Roche Applied Sciences, Nutley, NJ). The secondary antibodies were: horseradish-peroxidase (HRP)-conjugated goat antirabbit IgG (Pierce, Rockford, IL), HRP-conjugated rabbit anti-goat IgG (Pierce), and HRP-conjugated anti-rabbit IgG TrueBlot $^{\mathrm{TM}}$ (eBioscience, San Diego, CA).

\section{Cell Culture, Transfection and Membrane Preparation}

HEK-293 cells were grown in DMEM (Sigma) supplemented with $1 \mathrm{mM}$ sodium pyruvate, $2 \mathrm{mM}$ L-glutamine, $100 \mathrm{U} / \mathrm{ml}$ penicillin/streptomycin, $10 \%(\mathrm{v} / \mathrm{v})$ foetal bovine serum at $37^{\circ} \mathrm{C}$, and in an atmosphere of $5 \% \mathrm{CO}$. Cells were passaged 
when $80-90 \%$ confluent. For the transient expression of proteins, HEK-293 cells growing in $25 \mathrm{~cm}^{2}$ flasks were transiently transfected with $3 \mu \mathrm{g}$ of DNA by calcium phosphate precipitation (Jordan et al, 1996). Membrane suspensions from rat striatum or from transfected HEK cells were obtained as described previously (Casadó et al, 1990; Burgueño et al, 2004).

\section{Immunoprecipitation and Western Blot}

Rats were killed with an overdose of Equithesin and the brain was rapidly removed and striata dissected out. Membranes from transiently transfected HEK cells or rat striatum were solubilized in ice-cold lysis buffer (PBS, $\mathrm{pH}$ 7.4, containing $1 \%(\mathrm{v} / \mathrm{v})$ Nonidet P-40) for $30 \mathrm{~min}$ on ice. Solubilized preparations were then centrifuged at $13000 \mathrm{~g}$ for $30 \mathrm{~min}$. Supernatant $(1 \mathrm{mg} / \mathrm{ml})$ was processed for immunoprecipitation as described previously (Burgueño et al, 2003; Ferré et al, 2002), each step conducted with constant rotation at $0-4^{\circ} \mathrm{C}$, and incubated overnight with the indicated antibody. Forty microliters of a suspension of protein $G$ crosslinked to agarose beads were added and the mixture was incubated overnight. Beads were washed twice with ice-cold lysis buffer, twice with ice-cold lysis buffer containing $0.1 \%(\mathrm{v} / \mathrm{v})$ Nonidet P-40, once with ice-cold Tris-buffered saline, $\mathrm{pH}$ 7.4, and aspirated to dryness with a 28-gauge needle. Subsequently, $30 \mu \mathrm{l}$ of sodium dodecyl sulfate (SDS)-PAGE sample buffer (8 M Urea, 2\% SDS, $100 \mathrm{mM}$ DTT, $375 \mathrm{mM}$ Tris, $\mathrm{pH}$ 6.8) was added to each sample. Immune complexes were dissociated by heating to $37^{\circ} \mathrm{C}$ for $2 \mathrm{~h}$ and resolved by SDS-polyacrylamide gel electrophoresis in $10 \%$ gels. Proteins were transferred to polyvinylidene difluoride (PVDF) membranes using a semidry transfer system and immunoblotted with the indicated primary antibody and then the appropriate HRP-conjugated goat secondary antibody. Immunoreactive bands were developed using a chemiluminescent detection kit.

\section{RESULTS}

\section{Nicotine-Induced DA Release in the NAc Depends on Non- $\alpha_{7}$ nACh Receptors}

Basal extracellular levels of dialysate DA from the shell of the NAc were $3.7 \pm 0.2 \mathrm{nM}(n=65)$. Local perfusion of 1 and $10 \mathrm{mM}$ of nicotine in the NAc markedly increased extracellular levels of DA (ANOVA: $p<0.001$ in both cases; maximal increases of about $600 \%$ and $300 \%$ from basal values, respectively). The concentration of $1 \mathrm{mM}$ of nicotine produced a significantly more potent effect than $10 \mathrm{mM}$ of nicotine (two-way ANOVA: $p<0.05$ ) (Figure 1). The most effective concentration of nicotine $(1 \mathrm{mM})$ was chosen for the next experiments. Perfusion with $0.1 \mathrm{mM}$, but not $0.01 \mathrm{mM}$, of the broad-spectrum non- $\alpha_{7}$ nACh receptor antagonist $\mathrm{DH} \beta \mathrm{E}$ (Chavez-Noriega et al, 1997) produced a small but significant decrease in the extracellular concentration of DA (ANOVA: $p<0.05$; a maximal decrease of about $30 \%$ from basal values) (Figure 2). The simultaneous perfusion of $\mathrm{DH} \beta \mathrm{E}(0.1 \mathrm{mM})$ completely counteracted the DA release induced by $1 \mathrm{mM}$ of nicotine (Figure 2).

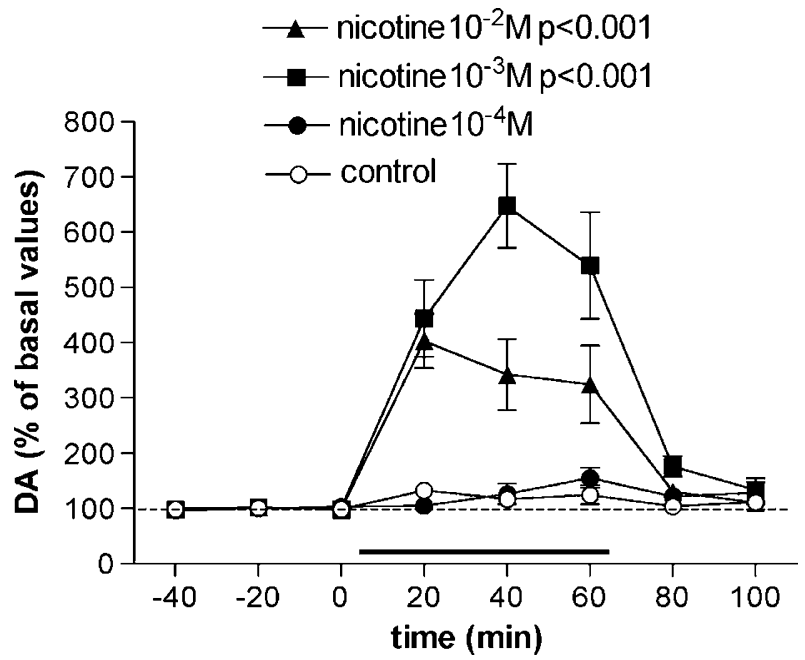

Figure I Extracellular concentrations of DA in the shell of the NAc after local perfusion of nicotine $(0$ (control), $0.1, \mathrm{I}$, and $10 \mathrm{mM})$. The horizontal line shows the period of perfusion. The results represent means \pm SEM of the percentage of basal values of the extracellular concentrations of DA ( $n=4-6$ per group). Basal values were the means of three values before drug perfusion. Nicotine I and $10 \mathrm{mM}$ produced a significant increase in the extracellular concentration of DA. Nicotine I mM was significantly more effective than nicotine $10 \mathrm{mM}$ (two-way ANOVA: $p<0.05$ ). The $p$-values refer to the significant differences between basal vs perfusion values for each treatment.

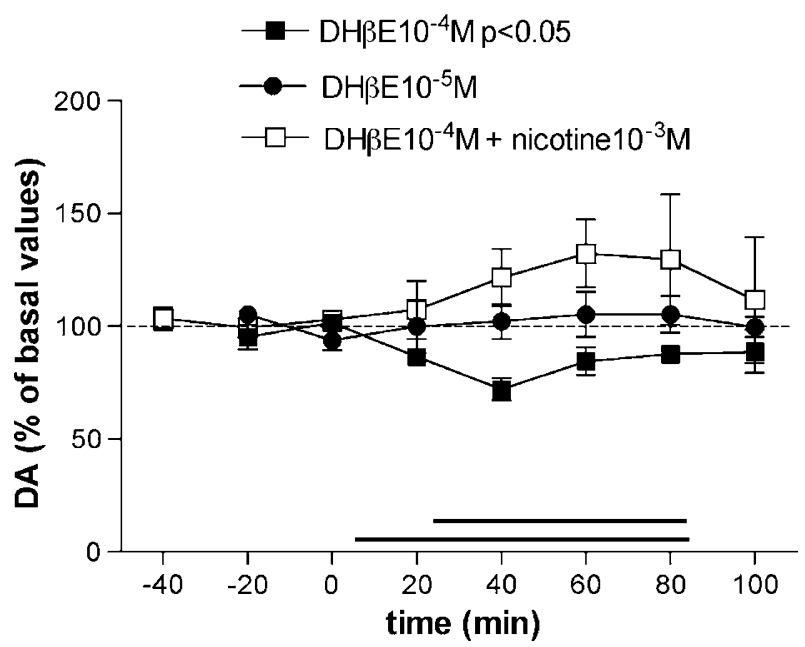

Figure 2 Extracellular concentrations of DA in the shell of the NAc after local perfusion of the non- $\alpha_{7} \mathrm{nACh}$ receptor antagonist $\mathrm{DH} \beta \mathrm{E}$ with or without coperfusion with nicotine ( I mM). The horizontal lines show the periods of perfusion; the upper line corresponds to nicotine and the lower line corresponds to $\mathrm{DH} \beta \mathrm{E}$. The results represent means $\pm \mathrm{SEM}$ of the percentage of basal values of the extracellular concentrations of DA ( $n=5-6$ per group). Basal values were the means of three values before drug perfusion. $D H B E 0.1 \mathrm{mM}$ produced a significant decrease in the extracellular concentration of DA and counteracted the increase in DA levels induced by nicotine I mM. The $p$-values refer to the significant differences between basal vs perfusion values for each treatment.

\section{DA $\mathrm{D}_{2}$ Receptor Stimulation Counteracts Nicotine-Induced DA Release}

Local perfusion of 0.001 and $0.01 \mathrm{mM}$ of the $\mathrm{D}_{2-3}$ receptor agonist quinpirole produced a dose-dependent decrease in 
extracellular levels of DA in the NAc (ANOVA: $p<0.05$ and $p<0.001$, respectively; maximal decreases of about 20 and $50 \%$ from basal values, respectively). The concentration of $0.01 \mathrm{mM}$ of quinpirole produced a significantly more potent effect than $0.001 \mathrm{mM}$ of quinpirole (two-way ANOVA: $p<0.05$ ) (Figure 3). When coperfused with nicotine $(1 \mathrm{mM})$, the lowest effective concentration of quinpirole (0.001 mM) completely counteracted nicotine-induced DA release (Figure 4$)$. In contrast, quinpirole $(1 \mu \mathrm{M})$ did not significantly modify the increase in extracellular levels of $\mathrm{DA}$ induced by the local perfusion of cocaine $(0.01 \mathrm{mM})$. Thus, cocaine produced maximal increases of about $100 \%$ from basal values in the presence and absence of quinpirole (ANOVA: $p<0.01$ in both cases) (Figure 4).

\section{Non- $\alpha_{7}$ nACh Receptor Blockade Counteracts DA Release Induced by $\mathrm{DA} \mathrm{D}_{2}$ Receptor Blockade}

Local perfusion with the $\mathrm{D}_{2-3}$ receptor antagonist raclopride produced a dose-dependent increase in extracellular levels of DA in the NAc, which was significant at concentrations of 0.001 and $0.01 \mathrm{mM}$ (ANOVA: $p<0.01$ and $p<0.001$, respectively; maximal increases of about 100 and $200 \%$ from basal values, respectively) (Figure 5). When coperfused with the non- $\alpha_{7} \mathrm{nACh}$ receptor antagonist $\mathrm{DH} \beta \mathrm{E}$ $(0.1 \mathrm{mM})$, the effect of raclopride $(0.01 \mathrm{mM})$ was significantly decreased (two-way ANOVA: $p<0.01$; to a maximal increase of DA of about $80 \%$ from basal values) (Figure 5).

\section{Co-immunoprecipitation of Non- $\alpha_{7}$ nAChRs and $D_{2}$ Autoreceptors from Co-Transfected HEK Cells and Striatal Tissue}

The possible existence of heteromeric receptor complexes between $\alpha_{4}$ or $\beta_{2}$ subunits of the non- $\alpha_{7} \mathrm{nACh}$ receptors and the $\mathrm{D}_{2}$ autoreceptor, which corresponds to the short isoform

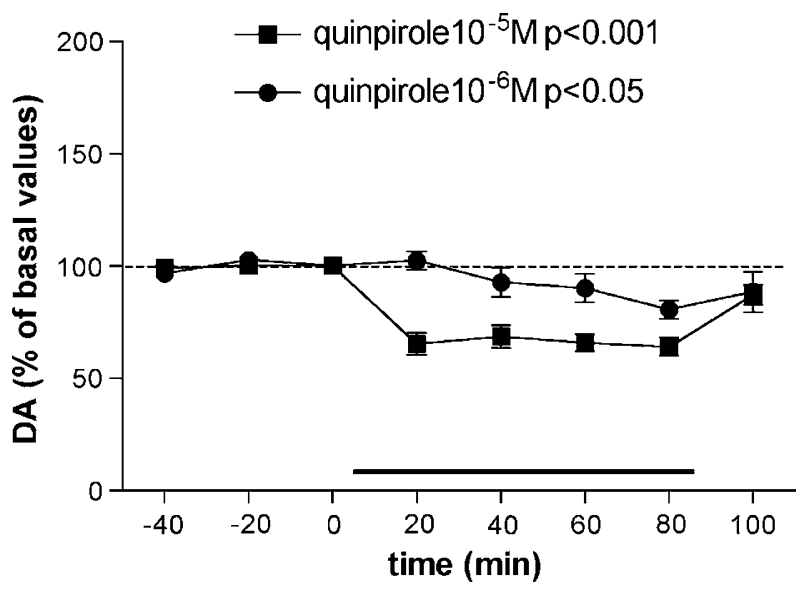

Figure 3 Extracellular concentrations of DA in the shell of the NAc after local perfusion of the $\mathrm{D}_{2-3}$ receptor agonist quinpirole. (0.00I and $0.01 \mathrm{mM}$ ). The horizontal line shows the period of perfusion. The results represent means \pm SEM of the percentage of basal values of the extracellular concentrations of DA ( $n=4-5$ per group). Basal values were the means of three values before drug perfusion. Quinpirole $0.00 \mathrm{I}$ and $0.01 \mathrm{mM}$ produced a significant decrease in the extracellular concentration of DA. Quinpirole $0.01 \mathrm{mM}$ was significantly more effective than quinpirole $0.001 \mathrm{mM}$ (two-way ANOVA: $p<0.05$ ). The $p$-values refer to the significant differences between basal vs perfusion values for each treatment. of the $\mathrm{D}_{2}$ receptor or $\mathrm{D}_{2 \mathrm{~S}}$ (Khan et al, 1998; Usiello et al, 2000; Rougé-Pont et al, 2002), was first studied in transiently co-transfected HEK cells. In extracts of cells

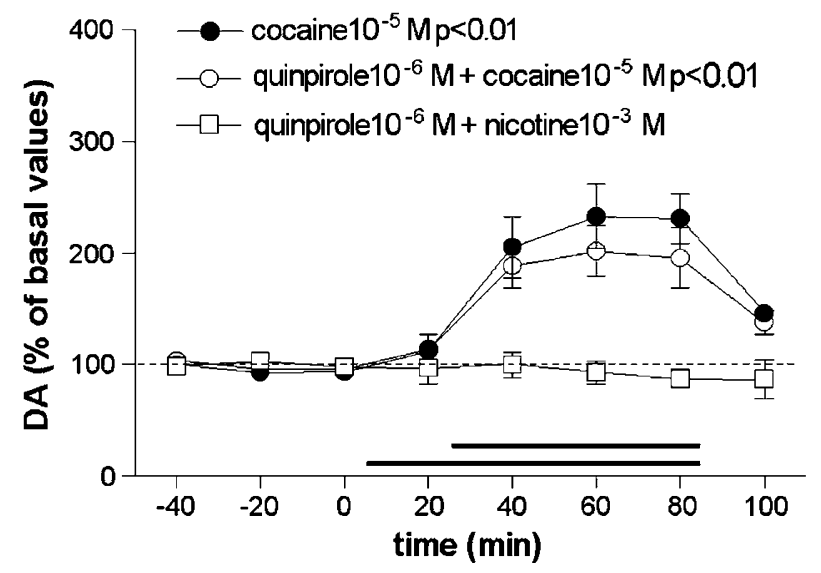

Figure 4 Extracellular concentrations of DA in the shell of the NAc after local perfusion of nicotine $(0.1 \mathrm{mM})$ or cocaine $(0.01 \mathrm{mM})$, with or without coperfusion with the $\mathrm{D}_{2-3}$ receptor agonist quinpirole $(0.001 \mathrm{mM})$. The horizontal lines show the periods of perfusion; the upper line corresponds to cocaine or nicotine and the lower line corresponds to quinpirole. The results represent means \pm SEM of the percentage of basal values of the extracellular concentrations of DA ( $n=5-6$ per group). Basal values were the means of three values before drug perfusion. Quinpirole $(0.001 \mathrm{mM})$ completely counteracted the increase in DA levels induced by nicotine $1 \mathrm{mM}$. Cocaine produced a significant increase in the extracellular concentration of DA, which was not significantly modified by quinpirole. The $p$-values refer to the significant differences between basal vs perfusion values for each treatment.

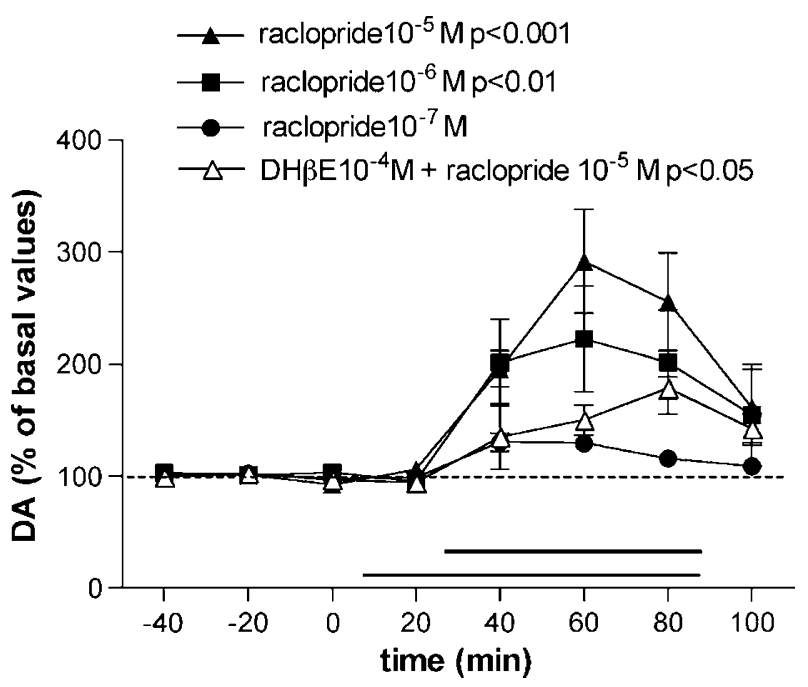

Figure 5 Extracellular concentrations of DA in the shell of the NAc after local perfusion of the $\mathrm{D}_{2-3}$ receptor antagonist raclopride $(0.000 \mathrm{I}, 0.00 \mathrm{I}$, and $0.01 \mathrm{mM}$ ) with or without coperfusion with of the non- $\alpha_{7} \mathrm{nACh}$ receptor antagonist $\mathrm{DH} \beta \mathrm{E}(0.1 \mathrm{mM})$. The horizontal lines show the period of perfusion; the upper line corresponds to raclopride and the lower line corresponds to $\mathrm{DH} \beta \mathrm{E}$. The results represent means $\pm \mathrm{SEM}$ of the percentage of basal values of the extracellular concentrations of DA ( $n=5-6$ per group). Basal values were the means of three values before drug perfusion. Raclopride 0.001 and $0.01 \mathrm{mM}$ produced a significant increase in the extracellular concentration of $\mathrm{DA}$. $\mathrm{DH} \beta \mathrm{E}$ significantly decreased the increase in the extracellular concentration of DA induced by raclopride $(0.01 \mathrm{mM})$ (two-way ANOVA: $p<0.0 \mathrm{I})$. The $p$-values refer to the significant differences between basal vs perfusion values for each treatment. 
transfected with $\alpha_{4}$-myc subunit, mouse anti-c-myc antibody immunoprecipitate revealed a band of $\sim 70 \mathrm{kDa}$, which corresponds to the $\alpha_{4}$ subunit of the human nACh receptor (Figure 6a). In extracts of cells transfected with $\beta_{2}$ subunit, rat anti- $\beta_{2}$ nACh receptor antibody immunoprecipitate revealed a band of $\sim 55 \mathrm{kDa}$, which corresponds to the $\beta_{2}$ subunit of the human nACh receptor (Figure 6a). In extracts of cells transfected with $\mathrm{D}_{2 \mathrm{~S}}-\mathrm{HA}$ receptor, mouse anti-HA antibody immunoprecipitate revealed a broad band of $\sim 55-75 \mathrm{kDa}$, which corresponds to the human $\mathrm{DA} \mathrm{D}_{2 \mathrm{~S}}$ receptor (Figure 6a). This broad immunoblot detection of $\mathrm{D}_{2 \mathrm{~s}}$ receptor most probably represents the different glycosylated states that this receptor shows when expressed in a heterologous system, as described previously (Fishburn et al, 1995). In extracts from cells co-transfected with $\alpha_{4}$ $m y c$ and $\beta_{2}$ subunits, anti-c-myc antibody co-immunoprecipitated the $\beta_{2}$ subunit of the nACh receptor and anti- $\beta_{2}$ antibody co-immunoprecipitated the $\alpha_{4}$ subunit of the nACh receptor (Figure 6a). Thus, as expected, in cotransfected HEK cells, $\alpha_{4}$ and $\beta_{2}$ subunits form heteromeric complexes. When $\mathrm{D}_{2 \mathrm{~S}}-\mathrm{HA}$ receptor was co-transfected with both $\alpha_{4}-m y c$ and $\beta_{2}$ subunits, anti-c-myc and anti- $\beta_{2}$ antibodies were able to co-immunoprecipitate the $\mathrm{D}_{2 \mathrm{~S}}$ receptor and, conversely, mouse anti-HA antibody coimmunoprecipitated $\alpha_{4}$ and $\beta_{2}$ subunits of the nACh receptor (Figure 6a). Importantly, the $\alpha_{4}$ subunit of the $\mathrm{nACh}$ receptor did not co-immunoprecipitate with $\mathrm{D}_{2 \mathrm{~S}}$ receptor in the absence of the $\beta_{2} \mathrm{nACh}$ receptor subunit (Figure 6a), indicating that the $\mathrm{D}_{2 S}$ receptor is able to establish heteromeric complexes with the nACh receptor by selectively interacting with the $\beta_{2}$ subunit.

We then analyzed the possible existence of heteromeric complexes in native brain preparations. To this end, we carried out similar co-immunoprecipitation experiments in soluble extracts from rat striatal membranes. As displayed in Figure $6 \mathrm{~b}$, the rabbit anti- $\beta_{2} \mathrm{nACh}$ receptor antibody immunoprecipitated a band of $\sim 55 \mathrm{kDa}$ corresponding to the $\beta_{2}$ nACh receptor (Figure 6b, lane 3, IB: $\beta_{2}$ ) (similar results were found using the rat anti- $\beta_{2} \mathrm{nACh}$ receptor antibody, data not shown) and the rabbit anti- $\mathrm{D}_{2}$ receptor antibody immunoprecipitated a broad band of $\sim 75-90 \mathrm{kDa}$ corresponding to the $\mathrm{D}_{2}$ receptor (Figure $6 \mathrm{~b}$, lane $2, \mathrm{IB}: \mathrm{D}_{2}$ ), as expected. Again, several glycosylated states of the $\mathrm{D}_{2}$ receptor tissue have been described in native brain (ClagettDame and McKelvy, 1989; Bjelke et al, 1996), which matches our current results. The divergence in $\mathrm{D}_{2}$ receptor size between native tissue and transient expression might reflect the different glycosylation machinery in both systems. Importantly, the anti- $\mathrm{D}_{2}$ receptor antibody was able to coimmunoprecipitate the $\beta_{2}$ subunit of the nACh receptor (Figure 6b, lane 2, IB: $\beta_{2}$ ) and, conversely, the rabbit anti- $\beta_{2}$ nACh receptor antibody co-immunoprecipitated the $\mathrm{D}_{2}$ receptor (Figure $6 \mathrm{~b}$, lane $3, \mathrm{IB}: \mathrm{D}_{2}$ ) (similar results were found using the rat anti- $\beta_{2}$ nAChR antibody, data not shown). Although the $\mathrm{D}_{2}$ receptor antibody used in these experiments does not differentiate between the short and long isoforms of $D_{2}$ receptor $\left(D_{2 S}\right.$ and $D_{2 L}$, respectively), in the striatum the $\beta_{2}$ subunits only colocalize with the $D_{2 S}$ receptor in the dopaminergic cell terminals (see Discussion). Therefore, these results indicate that heteromeric receptor complexes of $\mathrm{D}_{2}$ autoreceptors and $\mathrm{nACh}$ receptors containing $\beta_{2}$ subunits are present in the striatum in native a Transfection
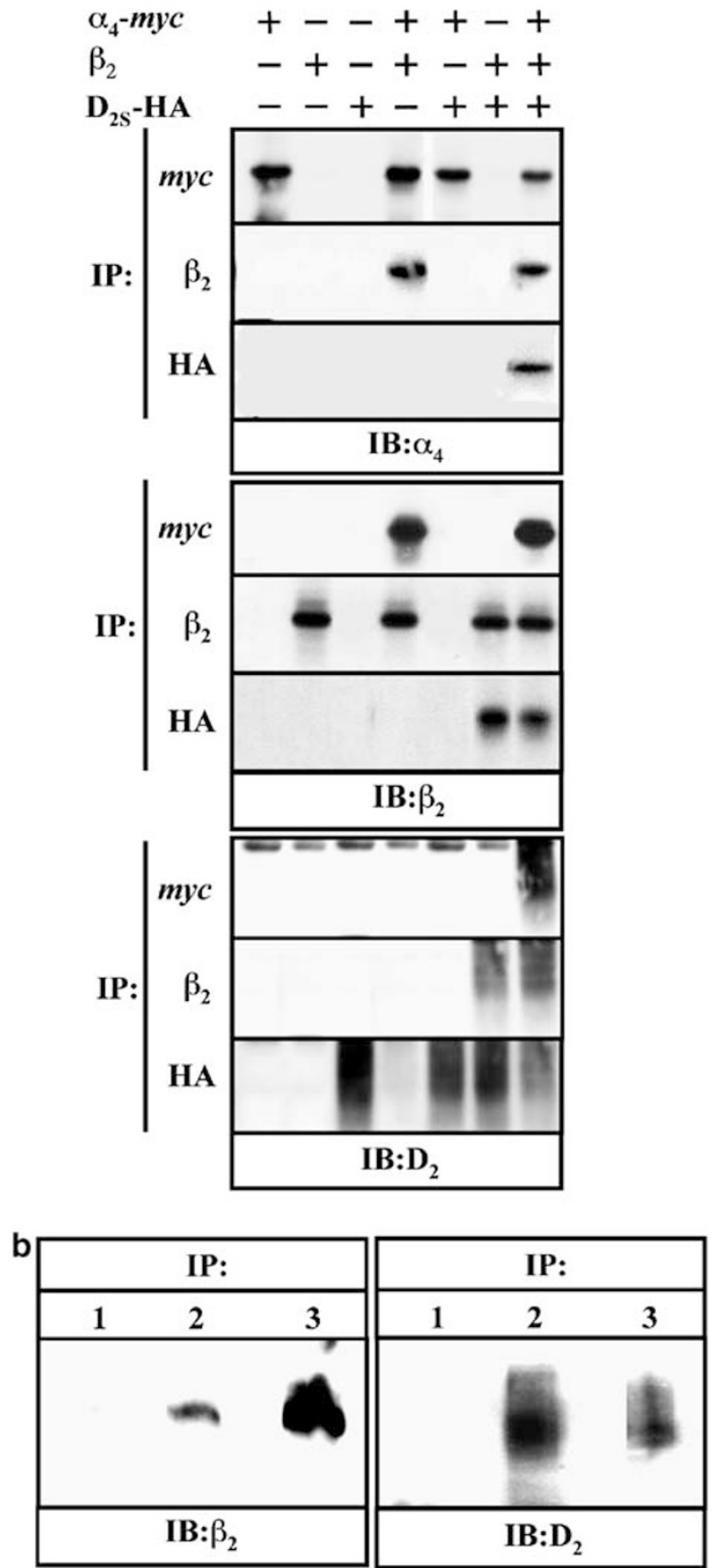

Figure 6 Co-immunoprecipitation of $n A C h$ and $D_{2}$ receptors. (a) HEK293 cells transiently transfected with the indicated human cDNAs were solubilized and processed for immunoprecipitation (IP) with mouse antimyc $(\mid \mu g)$, rat anti- $\beta_{2} \mathrm{nAch}$ receptor $(\mathrm{I} \mu \mathrm{g})$, and mouse anti-HA (I $\left.\mu \mathrm{g}\right)$ antibodies. Immunoprecipitates were analyzed by SDS-PAGE and immunoblotted (IB) using goat anti- $\alpha_{4} \mathrm{nACh}$ receptor antibody (I/500), rabbit anti- $\beta_{2} \mathrm{nACh}$ recepor antibody $(1 / 500)$, and rabbit anti- $\mathrm{D}_{2}$ receptor antibody (1/2000). The immunoreactive bands were visualized by chemiluminescence. (b) Rat striatal membranes were solubilized and processed for IP with rabbit irrelevant IgG (lane I), rabbit anti- $D_{2}$ receptor polyclonal antibody (lane 2), and rabbit anti- $\beta_{2} \mathrm{nACh}$ receptor polyclonal antibody (lane 3). Immunoprecipitates were analyzed by SDS-PAGE and IB using rabbit anti- $D_{2}$ receptor antibody $(1 / 2000)$ and rabbit anti- $\beta_{2} n A C h$ receptor antibody (1/500). A HRP-conjugated anti-rabbit IgG TrueBlot ${ }^{\mathrm{TM}}$ was used as a secondary antibody in order to avoid IgG crossreactivity. The immunoreactive bands were visualized by chemiluminescence. 
tissue, corroborating the previous results in transiently transfected cells.

\section{DISCUSSION}

In agreement with previous findings (Mifsud et al, 1989; Nakamura et al, 1992; Toth et al, 1992; Nisell et al, 1994; Marshall et al, 1997; Ferrari et al, 2002), we found that local perfusion of nicotine in the striatum (NAc) significantly increases the extracellular concentration of DA. Two main mechanisms that may be involved in this effect of nicotine have been suggested: (1), a direct stimulation of DA release by the activation of non- $\alpha_{7} \mathrm{nACh}$ receptors localized in dopaminergic terminals and (2), stimulation of DA release secondary to glutamate release (and activation of ionotropic glutamate receptors in the dopaminergic terminals) by the activation of $\alpha_{7} \mathrm{nACh}$ receptors localized in glutamatergic terminals (Toth et al, 1992; Kaiser and Wonnacott, 2000; Wonnacott et al, 2000; Zhou et al, 2001; Champtiaux et al, 2003; Rassoulpour et al, 2005). Our finding that the non- $\alpha_{7}$ $\mathrm{nACh}$ receptor antagonist $\mathrm{DH} \beta \mathrm{E}$ completely counteracted nicotine-induced DA release demonstrates that non- $\alpha_{7}$ $\mathrm{nACh}$ receptors play a fundamental role in the local DAreleasing effects of nicotine in the NAc. In fact, most striatal nACh receptors are heteromeric non- $\alpha_{7}$ nACh receptors (Zoli et al, 2002).

As in a recent study by Ferrari et al, (2002) we found that the extracellular concentration of DA in the NAc remained elevated during the whole period of nicotine perfusion (60 min) and went back to basal levels when nicotine perfusion was stopped. This effect was completely dependent on functional nACh receptors, as it was blocked with the nACh antagonist $\mathrm{DH} \beta \mathrm{E}$. These results are difficult to reconcile with the results obtained using in vitro models (fast voltametry in striatal slices), which suggest that exposure to DA induces a fast and potent desensitization of striatal non- $\alpha_{7}$ nACh that modulate DA release and that nicotine behaves as a non- $\alpha_{7} \mathrm{nACh}$ receptor antagonist (Zhou et al, 2001; Rice and Cragg, 2004). This suggests that the in vitro models (striatal slices) do not adequately model the in vivo situation. Nevertheless, in our study, desensitization could play some role in the weaker effects of nicotine at higher concentrations.

In previous in vivo microdialysis experiments, local perfusion with the non-selective nACh receptor antagonist mecamylamine was reported to be ineffective or even to induce an increase in striatal extracellular levels of DA (Nakamura et al, 1992; Nisell et al, 1994; Marshall et al, 1997; Fu et al, 2000). However, mecamylamine is nonselective, acting on both $\alpha_{7}$ and non- $\alpha_{7} \mathrm{nACh}$ receptors, and also has been shown to block NMDA receptors (Snell and Johnson, 1989). To our knowledge, this is the first report of the effects of local perfusion in the NAc of a selective non- $\alpha_{7}$ $\mathrm{nACh}$ receptor antagonist, $\mathrm{DH} \beta \mathrm{E}$, which produced a small but significant decrease in the extracellular concentration of DA. This indicates that endogenous ACh tonically modulates DA release by acting on non- $\alpha_{7} \mathrm{nACh}$ receptors, as previously suggested by Zhou et al, (2001).

The effects of local and systemic administration of $\mathrm{D}_{2}$ receptor agonists and antagonists on striatal DA release have been repeatedly shown in the literature (for specific effects in the NAc see, for instance, See et al, 1991; Ferré and Artigas, 1995) and they have been demonstrated to depend on $\mathrm{D}_{2 \mathrm{~S}}$ autoreceptors (Khan et al, 1998; Usiello et al, 2000; Rougé-Pont et al, 2002). In agreement, we found that local perfusion of the $\mathrm{D}_{2-3}$ receptor agonist quinpirole significantly decreased, whereas the $\mathrm{D}_{2-3}$ receptor antagonist raclopride increased, the extracellular concentration of DA in the NAc. A major finding of the present study was that a concentration of quinpirole $(1 \mu \mathrm{M})$ that slightly inhibited DA release (20\% below basal values) completely counteracted the very large increase in the extracellular levels of DA (about $600 \%$ above basal values) induced by nicotine in the NAc. On the other hand, the same concentration of quinpirole $(1 \mu \mathrm{M})$ did not significantly modify cocaineinduced DA release. These findings demonstrate a potent crosstalk between GPCRs and ligand-gated ion channels in dopaminergic nerve terminals, with the $\mathrm{D}_{2}$ autoreceptor modulating the efficacy of non- $\alpha_{7} \mathrm{nACh}$ receptor-mediated modulation of DA release. Furthermore, the significant counteractive effect of $\mathrm{DH} \beta \mathrm{E}$ on raclopride-induced increases in the extracellular concentrations of DA strongly suggests that inhibition of non- $\alpha_{7}$ nACh striatal receptor function is a main mechanism by which $\mathrm{D}_{2}$ autoreceptors control DA release.

An increasing number of receptor interactions are being demonstrated to depend on their physical association, forming functional heteromeric receptor complexes and often heterodimers (Bouvier, 2001; Devi, 2001; Agnati et al, 2003; Lee et al, 2003). This includes the possibility of heteromeric receptor complexes of GPCRs and ligand-gated ion channels, such as the DA $\mathrm{D}_{1}$-NMDA and the DA $\mathrm{D}_{5^{-}}$ $\mathrm{GABA}_{\mathrm{A}}$ receptor interactions (reviewed in Agnati et al, 2003). The present experiments with co-transfected HEK cells demonstrate that the $D_{2 S}$ receptor is able to establish heteromeric complexes with the nACh receptor by selectively interacting with the $\beta_{2}$ subunit when coexpressed in the same cells. Furthermore, an antibody against the $\beta_{2}$ subunit of the nAch receptor was able to co-immunoprecipitate $\mathrm{D}_{2}$ receptors from membrane preparations of the rat striatum and, conversely, a $\mathrm{D}_{2}$ receptor antibody was able to co-immunoprecipitate the $\beta_{2}$ subunit of the nAch receptor. Since in the striatum the $\beta_{2}$ subunits of the nAch receptor are mostly localized in the dopaminergic cell terminals (Wonnacott et al, 2000; Jones et al, 2001; Zoli et al, 2002), where they are colocalized with $\mathrm{D}_{2 \mathrm{~S}}$ autoreceptors, the present results show that non- $\alpha_{7}$ nAChRs containing $\beta_{2}$ subunits form part of a heteromeric $D_{2}$ autoreceptor complex, which exerts strong control over striatal DA release.

The term autoreceptor was introduced to define those receptors localized in nerve terminals that respond to the neurotransmitter released by the same neuron (Langer, 1974). Later, the term autoreceptor also included receptors localized in the somatodendritic region that respond to somatodendritic neurotransmitter release (Aghajanian and Bunney, 1977). Functionally, autoreceptors act as a feedback mechanism inhibiting neurotransmitter release. The term heteroreceptor is used for presynaptic receptors capable of regulating (stimulating or inhibiting) the release of neurotransmitter other than their own, which is one of the main functions of nACh receptors in the central nervous system (Wonnacott, 1997). The term heteromeric auto- 
receptor complex expands the concepts of autoreceptor and heteroreceptor, to include them in a functional macromolecular complex. The present study shows that striatal dopaminergic neurotransmission is under the control of heteromeric autoreceptor complexes containing $\mathrm{D}_{2}$ autoreceptors and non- $\alpha_{7}$ ACh heteroreceptors. It still remains to be determined if the functional interaction between these two receptors depends on their physical interaction and if they establish a direct physical interaction ('true heteromerization'), as co-immunoprecipitation does not discard the existence of intermediate linking proteins. Nevertheless, the experiments in co-transfected HEK cells favor the hypothesis of a selective direct interaction between $\beta_{2}$ subunits of the nACh receptors and $\mathrm{D}_{2}$ autoreceptors, as the $\alpha_{4}$ subunit of the $\mathrm{nACh}$ receptor could co-immunoprecipitate with $\mathrm{D}_{2 \mathrm{~S}}$ receptor only in the presence of the $\beta_{2} \mathrm{nACh}$ receptor subunit. Otherwise, the heteromeric nACh-DA autoreceptor complexes should also contain some proteins that would be constitutively expressed in HEK cells and that would physically and specifically link the $\beta_{2} \mathrm{nACh}$ receptor subunit to the $\mathrm{D}_{2 \mathrm{~S}}$ receptor. It must also be pointed out that $\mathrm{D}_{2}$ autoreceptors and non- $\alpha_{7} \mathrm{nACh}$ receptors are not only co-localized in the terminals of dopaminergic cells but also in their soma and dendrites (Aghajanian and Bunney, 1977), suggesting that heteromeric receptor complexes are also present in the ventral tegmental area. The present study provides new evidence against the generalized simplistic notion of the neurotransmitter receptor as a single functional entity and, to our knowledge, it is the first example of presynaptic heteromeric receptor complexes that include ligand-gated ion channels and GPCRs that modulate neurotransmitter release.

\section{ACKNOWLEDGEMENTS}

This work was supported by the National Institute on Drug Abuse Intramural Research Funds. F Ciruela is currently holding a Ramón y Cajal research contract signed with the Ministerio de Educación y Ciencia. This work was supported by Grant SAF2002-03293 to RF and SAF200500903 to FC from Ministerio de Educación y Ciencia.

\section{REFERENCES}

Aghajanian GK, Bunney BS (1977). Dopamine 'autoreceptors': pharmacological characterization by microiontophoretic single cell recording studies. Naunyn Schmiedeberg's Arch Pharmacol 297: 1-7.

Agnati LF, Ferré S, Lluis C, Franco R, Fuxe K (2003). Molecular mechanisms and therapeutical implications of intramembrane receptor/receptor interactions among heptahelical receptors with examples from the striatopallidal GABA neurons. Pharmacol Rev 55: 509-550.

Bjelke B, Goldstein M, Tinner B, Andersson C, Sesack SR, Steinbusch HWM et al (1996). Dopaminergic transmission in the rat retina: evidence for volume transmissión. J Chem Neuroanat 12: 37-50.

Bouvier M (2001). Oligomerization of G-protein-coupled transmitter receptors. Nat Rev Neurosci 2: 274-286.

Burgueño J, Canela EI, Mallol J, Lluis C, Franco R, Ciruela F (2004). Mutual regulation between metabotropic glutamate type lalpha receptor and caveolin proteins: from traffic to constitutive activity. Exp Cell Res 300: 23-34.
Burgueño J, Enrich C, Canela EI, Mallol J, Lluis C, Franco R et al (2003). Metabotropic glutamate type 1alpha receptor localizes in low-density caveolin-rich plasma membrane fractions. J Neurochem 86: 785-791.

Casadó V, Canti C, Mallol J, Canela EI, Lluis C, Franco R (1990). Solubilization of A1 adenosine receptor from pig brain: characterization and evidence of the role of the cell membrane on the coexistence of high- and low-affinity states. J Neurosci Res 26: 461-473.

Cass WA, Zahniser NR (1991). Potassium channel blockers inhibit D2 dopamine, but not A1 adenosine, receptormediated inhibition of striatal dopamine release. J Neurochem 57: 147-152.

Champtiaux N, Gotti C, Cordero-Erausquin M, David DJ, Przybylski C, Lena C et al (2003). Subunit composition of functional nicotinic receptors in dopaminergic neurons investigated with knock-out mice. J Neurosci 23: 7820-7829.

Chavez-Noriega LE, Crona JH, Washburn MS, Urrutia A, Elliott KJ, Johnson EC (1997). Pharmacological characterization of recombinant human neuronal nicotinic acetylcholine receptors $h$ alpha 2 beta 2 , h alpha 2 beta 4 , h alpha 3 beta 2 , h alpha 3 beta $4, \mathrm{~h}$ alpha 4 beta 2, h alpha 4 beta 4 and h alpha 7 expressed in Xenopus oocytes. J Pharmacol Exp Ther 280: 346-356.

Clagett-Dame M, McKelvy JF (1989). N-linked oligosaccharides are responsible for rat striatal dopamine D2 receptor heterogeneity. Arch Biochem Biophys 274: 145-154.

Clarke PB, Reuben M (1996). Release of $\left[{ }^{3} \mathrm{H}\right]$-noradrenaline from rat hippocampal synaptosomes by nicotine: mediation by different nicotinic receptor subtypes from striatal $\left[{ }^{3} \mathrm{H}\right]$-dopamine release. Br J Pharmacol 117: 595-606.

Congar P, Bergevin A, Trudeau LE (2002). D2 receptors inhibit the secretory process downstream from calcium influx in dopaminergic neurons: implication of $\mathrm{K}^{+}$channels. J Neurophysiol 87: $1046-1056$.

Devi LA (2001). Heterodimerization of G-protein-coupled receptors: pharmacology, signaling and trafficking. Trends Pharmacol Sci 2: 532-537.

Engelman HS, MacDermott AB (2004). Presynaptic ionotropic receptors and control of transmitter release. Nat Rev Neurosci 5: 135-145.

Ferrari R, Le Novere N, Picciotto MR, Changeux JP, Zoli M (2002). Acute and long-term changes in the mesolimbic dopamine pathway after systemic or local single nicotine injections. Eur J Neurosci 15: 1810-1818.

Ferré S, Artigas F (1995). Clozapine decreases serotonin extracellular levels in the nucleus accumbens by a dopamine receptorindependent mechanism. Neurosci Lett 187: 61-64.

Ferré S, Karcz-Kubicha M, Hope BT, Popoli P, Burgueno J, Gutierrez MA et al (2002). Synergistic interaction between adenosine A2A and glutamate mGlu5 receptors: implications for striatal neuronal function. Proc Natl Acad Sci USA 99: 1194011945.

Fishburn CS, Elazar Z, Fuchs S (1995). Differential glycosylation and intracellular trafficking for the long and short isoforms of the D2 dopamine receptor. J Biol Chem 270: 29819-29824.

$\mathrm{Fu}$ Y, Matta SG, Gao W, Sharp BM (2000). Local alphabungarotoxin-sensitive nicotinic receptors in the nucleus accumbens modulate nicotine-stimulated dopamine secretion in vivo. Neuroscience 101: 369-375.

Grady SR, Murphy KL, Cao J, Marks MJ, McIntosh JM, Collins AC (2002). Characterization of nicotinic agonist-induced $[(3) \mathrm{H}]$ dopamine release from synaptosomes prepared from four mouse brain regions. J Pharmacol Exp Ther 301: 651-660.

Gulley JM, Zahniser NR (2003). Rapid regulation of dopamine transporter function by substrates, blockers and presynaptic receptor ligands. Eur J Pharmacol 479: 139-152.

Jones IW, Bolam JP, Wonnacott S (2001). Presynaptic localisation of the nicotinic acetylcholine receptor beta2 subunit immunor- 
eactivity in rat nigrostriatal dopaminergic neurones. J Comp Neurol 439: 235-247.

Jordan M, Schallhorn A, Wurm FM (1996). Transfecting mammalian cells: optimization of critical parameters affecting calciumphosphate precipitate formation. Nucleic Acids Res 24: 596-601.

Kaiser S, Wonnacott S (2000). Alpha-bungarotoxin-sensitive nicotinic receptors indirectly modulate $[(3) \mathrm{H}]$ dopamine release in rat striatal slices via glutamate release. Mol Pharmacol 58: 312-318.

Khan ZU, Mrzljak L, Gutierrez A, de la Calle A, GoldmanRakic PS (1998). Prominence of the dopamine D2 short isoform in dopaminergic pathways. Proc Natl Acad Sci USA 95: 7731-7736.

Kulak JM, McIntosh JM, Yoshikami D, Olivera BM (2001). Nicotine-evoked transmitter release from synaptosomes: functional association of specific presynaptic acetylcholine receptors and voltage-gated calcium channels. J Neurochem 77: 1581-1589.

Langer SZ (1974). Presynaptic regulation of catecholamine release. Biochem Pharmacol 23: 1793-1800.

Lee SP, O'Dowd BF, George SR (2003). Homo- and heterooligomerization of $\mathrm{G}$ protein-coupled receptors. Life Sci 4: 173-180.

Marshall DL, Redfern PH, Wonnacott S (1997). Presynaptic nicotinic modulation of dopamine release in the three ascending pathways studied by in vivo microdialysis: comparison of naive and chronic nicotine-treated rats. J Neurochem 68 1511-1519.

Matthews JN, Altman DG, Campbell MJ, Royston P (1990). Analysis of serial measurements in medical research. BMJ 300: 230-235.

Mifsud JC, Hernandez L, Hoebel BG (1989). Nicotine infused into the nucleus accumbens increases synaptic dopamine as measured by in vivo microdialysis. Brain Res 478: 365-367.

Nakamura S, Goshima Y, Yue JL, Miyamae T, Misu Y (1992). Transmitter-like 3,4-dihydroxyphenylalanine is tonically released by nicotine in striata of conscious rats. Eur J Pharmacol 222: $75-80$.

Nisell M, Nomikos GG, Svensson TH (1994). Systemic nicotineinduced dopamine release in the rat nucleus accumbens is regulated by nicotinic receptors in the ventral tegmental area. Synapse 16: 36-44.

Onali P, Olianas MC, Bunse B (1988). Evidence that adenosine A2 and dopamine autoreceptors antagonistically regulate tyrosine hydroxylase activity in rat striatal synaptosomes. Brain Res 456: 302-309.

Pontieri FE, Tanda G, Di Chiara G (1995). Intravenous cocaine, morphine, and amphetamine preferentially increase extracellular dopamine in the 'shell' as compared with the 'core' of the rat nucleus accumbens. Proc Natl Acad Sci USA 92: 12304-12308.
Pothos EN, Przedborski S, Davila V, Schmitz Y, Sulzer D (1998). D2-like dopamine autoreceptor activation reduces quantal size in PC12 cells. J Neurosci 18: 5575-5585.

Rassoulpour A, Wu HQ, Ferré S, Schwarcz R (2005). Nanomolar concentrations of kynurenic acid reduce extracellular dopamine levels in the striatum. J Neurochem 93: 762-765.

Rice ME, Cragg SJ (2004). Nicotine amplifies reward-related dopamine signals in striatum. Nat Neurosci 7: 583-584.

Rougé-Pont F, Usiello A, Benoit-Marand M, Gonon F, Piazza PV, Borrelli E (2002). Changes in extracellular dopamine induced by morphine and cocaine: crucial control by D2 receptors. J Neurosci 22: 3293-3301.

Sacaan AI, Dunlop JL, Lloyd GK (1995). Pharmacological characterization of neuronal acetylcholine gated ion channel receptor-mediated hippocampal norepinephrine and striatal dopamine release from rat brain slices. J Pharmacol Exp Ther 274: 224-230.

See RE, Sorg BA, Chapman MA, Kalivas PW (1991). In vivo assessment of release and metabolism of dopamine in the ventrolateral striatum of awake rats following administration of dopamine D1 and D2 receptor agonists and antagonists. Neuropharmacol 30: 1269-1274.

Snell LD, Johnson KM (1989). Effects of nicotinic agonists and antagonists on $\mathrm{N}$-methyl-D-aspartate-induced ${ }^{3} \mathrm{H}$-norepinephrine release and ${ }^{3} \mathrm{H}-(1-[1-(2-$ thienyl)cyclohexyl]-piperidine) binding in rat hippocampus. Synapse 3: 129-135.

Toth E, Sershen H, Hashim A, Vizi ES, Lajtha A (1992). Effect of nicotine on extracellular levels of neurotransmitters assessed by microdialysis in various brain regions: role of glutamic acid. Neurochem Res 17: 265-271.

Usiello A, Baik JH, Rouge-Pont F, Picetti R, Dierich A, LeMeur M et al (2000). Distinct functions of the two isoforms of dopamine D2 receptor. Nature 408: 199-203.

Vizi ES, Lendvai B (1999). Modulatory role of presynaptic nicotinic receptors in synaptic and non-synaptic chemical communication in the central nervous system. Brain Res Brain Res Rev 30: 219235.

Wonnacott S (1997). Presynaptic nicotinic ACh receptors. Trends Neurosci 20: 92-98.

Wonnacott S, Kaiser S, Mogg A, Soliakov L, Jones IW (2000). Presynaptic nicotinic receptors modulating dopamine release in the rat striatum. Eur J Pharmacol 393: 51-58.

Zhou FM, Liang Y, Dani JA (2001). Endogenous nicotinic cholinergic activity regulates dopamine release in the striatum. Nat Neurosci 4: 1224-1229.

Zoli M, Moretti M, Zanardi A, McIntosh JM, Clementi F, Gotti C (2002). Identification of the nicotinic receptor subtypes expressed on dopaminergic terminals in the rat striatum. J Neurosci 22: 8785-8789. 